\title{
Isogambogenic Acid Inhibits the Growth of Glioma Through Activation of the AMPK-mTOR Pathway
}

\author{
Wenyang Zhao Fei Penga,b Mengting Shu ${ }^{a, b}$ Huailei Liu ${ }^{a, b} \quad$ Xu Hou ${ }^{a, b}$ \\ Xiaoxiong Wang ${ }^{a, b}$ Junyi Ye $e^{a, b}$ Boxian Zhao Kaikai Wang ${ }^{a, b} \quad$ Chen Zhong ${ }^{a, b}$ \\ Linmeng Xue ${ }^{a, b}$ Ming Gao ${ }^{a, b} \quad$ Yaohua Liü ${ }^{a, b}$ Shiguang Zhao \\ aDepartment of Neurosurgery, The First Affiliated Hospital of Harbin Medical University, Harbin, \\ 'Institute of Brain Science, Harbin Medical University, Harbin, People's Republic of China
}

\section{Key Words}

Isogambogenic acid • Autophagy • AMPK-mTOR • Apoptosis • Glioma

\begin{abstract}
Background/Aims: Glioma is the most devastating cancer in the brain and has a poor prognosis in adults. Therefore, there is a critical need for novel therapeutic strategies for the management of glioma patients. Isogambogenic acid, an active compound extracted from the Chinese herb Garcinia hanburyi, induces autophagic cell death. Methods: Cell viability was detected with MTT assays. Cell proliferation was assessed using the colony formation assay. Morphological changes associated with autophagy and apoptosis were tested by TEM and Hoechst staining, respectively. The apoptosis rate was measured by flow cytometry. Western blot, immunofluorescence and immunohistochemical analyses were used to detect protein expression. U87-derived xenografts were established for the examination of the effect of isogambogenic acid on glioma growth in vivo. Results: Isogambogenic acid induced autophagic death in U87 and U251 cells, and blocking late-stage autophagy markedly enhanced the antiproliferative activities of isogambogenic acid. Moreover, we observed the activation of AMPK-mTOR signalling in isogambogenic acid-treated glioma cells. Furthermore, the activation of AMPK or the inhibition of mTOR augmented isogambogenic acid-induced autophagy. Inhibition of autophagy attenuated apoptosis in isogambogenic acid-treated glioma cells. Finally, isogambogenic acid inhibited the growth of U87 glioma in vivo. Conclusion: Isogambogenic acid inhibits the growth of glioma via activation of the AMPK-mTOR signalling pathway, which may provide evidence for future clinical applications in glioma therapy.
\end{abstract}

Shiguang Zhao

and Yaohua Liu

KARGER
Department of Neurosurgery and Institute of Brain Science, The First Affiliated Hospital of Harbin Medical University, Youzheng Street No.23, Nangang District, Harbin, Heilongjiang Province (China);

Tel. +86-451-85552799, E-Mail guangsz@hotmail.com/liuyaohua_harbin@hotmail.com 


\section{Introduction}

Glioma is the most common primary brain tumour in adults [1]. Although surgery, chemotherapy, radiotherapy and other treatment methods have made great progress, the prognosis of glioma patients is still very poor, and the median survival is only 16 to 19 months $[2,3]$. Therefore, there is an urgent need for effective drugs that prolong the survival time of patients.

Autophagy is a conserved process that captures, degrades, and recycles organelles, proteins and other substances in cells, but excessive autophagy may induce cell death [4]. Autophagy can be activated in many kinds of cells, including gliomas. Cytotoxic drugs cause damage to DNA, cellular proteins, and organelles and promote cell autophagic death [5]. The consequences of autophagy activation in response to drugs can be significantly different due to cellular conditions and distinct cancer subtypes $[6,7]$. The autophagy inhibitor 3-methyladenine (3-MA) suppresses the early stage of autophagy, while chloroquine (CQ) leads to the accumulation of autophagic vacuoles and inhibits the late stage of autophagy [8]. Autophagy can induce cancer cell death independent of or in conjunction with apoptosis [9]. Many pre-clinical studies have investigated AMP-activated protein kinase (AMPK) in various cancers, such as ovarian cancer, liver cancer, lung cancer and glioma [10,11]. Mammalian target of rapamycin (mTOR) is a serine/threonine protein kinase that regulates cell growth, ageing, metabolism, protein synthesis, and transcription through changes in nutrients, cellular energy stage and growth factors $[12,13]$. In addition, the activity of mTOR is usually up-regulated in cancers, including gliomas [14]. Moreover, activation of AMPK leads to the inhibition of mTOR activity and further regulates autophagy [15-17].

Isogambogenic acid is one of the major active compounds extracted from a traditional Chinese medicinal herb named Garcinia hanburyi, which is distributed throughout Thailand, Cambodia, India, and the southern part of China and mainly used to treat abscesses, poisoning, tinea infections, bleeding injuries, dental caries, and burns. Recent studies showed that isogambogenic acid has anti-tumour effects on lung carcinoma cells by inhibiting angiogenesis and promoting autophagy-dependent cell death [18]. However, the underlying molecular mechanisms of autophagy by isogambogenic acid-induced is still unclear, especially in glioma.

In the present study, we found that isogambogenic acid induces autophagic death through activation of the AMPK-mTOR pathway in glioma cells. In all, our results showed that isogambogenic acid may be a potential therapeutic drug for the treatment of glioma.

\section{Materials and Methods}

\section{Cell culture}

Human U87 and U251 glioma cell lines were provided by the Institute of Brain Science of the First Affiliated Hospital (Harbin Medical University, China). Human U87 and U251 glioma cells were cultured in Dulbecco's modified Eagle's medium (Corning, 10-017-CVR) with 10\% foetal bovine serum (FBS; Invitrogen) and $1 \%$ penicillin/streptomycin (Sigma-Aldrich, USA) at $37{ }^{\circ} \mathrm{C}$ in a humidified incubator at $5 \% \mathrm{CO}_{2}$. Cells were grown to $70 \%$ to $80 \%$ confluence in cell culture plates and treated under the indicated conditions.

\section{Reagents}

Isogambogenic acid (ChemFaces, CFN92096) was prepared as a solution in dimethyl sulfoxide (DMSO) and diluted to the indicated concentrations. Rapamycin (Rapa, R8781), chloroquine (CQ C6628), and 3-methyladenine (3-MA, M9281) were purchased from Sigma-Aldrich (St. Louis, MO, USA). Metformin hydrochloride was obtained from Med ChemExpress (Met; HY-17471A). The primary antibodies used in this study recognized the following proteins: caspase-3 (Cell Signaling Technology, 9662), cleaved-caspase-3 (Cell Signaling Technology, 9661), p62/SQSTM1 (Sigma-Aldrich, P0067), LC3 (Sigma-Aldrich, L7543), $\beta$-actin (Abclonal Technology, AC004), Ki67 (Abclonal, A2094), p-AMPK Thr172 (Cell Signaling Technology, 


\section{Cellular Physiology Cell Physiol Biochem 2017;44:1381-1395 \begin{tabular}{ll|l} 
DOI: 10.1159/000485535 & O 2017 The Author(s). Published by S. Karger AG, Basel \\
www.karger.com/cpb
\end{tabular} \\ Zhao et al.: Isogambogenic Acid Inhibits Gliom Growth via AMPK-mTOR}

2535), AMPK (Cell Signaling Technology, 2532), mTOR (Cell Signaling Technology, 2983), p-mTOR Ser2448 (Cell Signaling Technology, 5536), 4E-BP1 (Cell Signaling Technology, 9644), or p-4E-BP1 Thr43/46 (Cell Signaling Technology, 2855).

\section{Measurement of cell viability}

Human U87 and U251 glioma cell viabilities were detected by the 3-(4, 5-dimethylthiazol-2-yl)-2, 5-diphenyltetrazolium bromide (MTT; Sigma, M5655) method. Cells were seeded in 96-well culture plates and treated. Then, $20 \mu \mathrm{l}$ of MTT ( $5 \mathrm{mg} / \mathrm{ml}$ ) was added to each well. After a $4 \mathrm{~h}$ incubation, the supernatant was aspirated and $150 \mu \mathrm{l}$ of DMSO was added to each well. At last, cell viability was estimated colorimetrically at $570 \mathrm{~nm}$ by an M200 plate reader (TECAN, Switzerland). The value of the absorbance in each group was normalized to that in the control group.

\section{Colony formation assay}

Briefly, 500 cells/well were seeded into a six-well plate. After full attachment, the cells were continuously cultured in the presence or absence of isogambogenic acid for $14 \mathrm{~d}$. Clones were stained with $0.1 \%$ crystal violet for $15 \mathrm{~min}$ and photographed using the ChemiDocTM MP System (Bio-Rad, USA). Only those cell clusters containing more than 50 cells were counted.

\section{Cell cycle analysis}

Glioma cells were cultured with various concentrations of isogambogenic acid for $24 \mathrm{~h}$ and then suspended in $70 \%$ ethanol and fixed overnight at $4{ }^{\circ} \mathrm{C}$. Cell cycle was detected using the Cell Cycle and Apoptosis Analysis Kit (Beyotime, P0010) according to the manufacturer's protocol with an Accuri C6 flow cytometer (BD Bioscience). The distribution of cells in G0/G1, S, and G2M phases was calculated using the ModFit LT software.

\section{Transfection with adenovirus expressing the GFP-LC3B fusion protein}

An adenovirus expressing the GFP-LC3B fusion protein (Ad-GFP-LC3B) was purchased from Beyotime, China. Cells grown to approximately $70 \%$ confluence were transfected with Ad-GFP-LC3B according to the manufacturer's instructions. Ad-GFP-LC3B-transduced glioma cells were treated with DMSO or different concentrations of isogambogenic acid, visualized by fluorescence microscopy and quantified with Image Lab software.

\section{Western blot}

Glioma cells $\left(3 \times 10^{5}\right.$ cells/well $)$ were seeded onto 6 - $\mathrm{cm}$ dishes and treated according to the different experiments. Cells were harvested and then collected in RIPA lysis buffer (Thermo Scientific, USA) with protease and phosphatase cocktail inhibitors (Roche, 05892970001, 4906845001). The protein concentrations of each sample were quantified by BCA assay (Beyotime, P0010) according to the manufacturer's instructions. Total protein (20-100 $\mu \mathrm{g})$ was separated by 6-15\% SDS-PAGE gels and then transferred onto polyvinyl difluoride (PVDF) membranes (Millipore, IPVH00010) by the wet transfer method (Bio-Rad, USA). The membranes were blocked at room temperature for $1 \mathrm{~h}$ and were incubated with the indicated primary antibodies on an orbital shaker at $4{ }^{\circ} \mathrm{C}$ overnight. After washing with TBST, the HRP conjugated secondary antibody (ZSGBBI0, ZF-2301, ZF-2305) was applied for 1 hour at room temperature. Western blots were visualized using BeyoECL Star (Beyotime, P0018A) detection and quantified with Image Lab software.

\section{Immunofluorescence}

Cells $\left(5 \times 10^{4}\right)$ were seeded onto $35-\mathrm{mm}$ glass-bottomed dishes. Cells were treated according to the different experiments and fixed with $4 \%$ paraformaldehyde. Subsequently, cells were permeabilized using 0.1\% Triton X-100 for 15 min and blocked with 10\% bovine serum albumin (BSA; BOSTER, AR0004) for 1 h. Primary antibodies were diluted in $1 \% \mathrm{BSA}$ and incubated at $4{ }^{\circ} \mathrm{C}$ overnight. After incubating for $1 \mathrm{~h}$ at $37^{\circ} \mathrm{C}$ with AlexaFluor 488 AffiniPure goat anti-rabbit IgG (H+L) (ZSGBBIO, ZF-0155) in the dark, cells were incubated with DAPI (Beyotime, C1005) in a cassette for 5 min in the dark. Images were captured by the FSX100 Bio Imaging Navigator (Olympus, Japan). Data were standardized by Image-Pro Plus 6.0. 


\section{Cellular Physiology Cell Physiol Biochem 2017;44:1381-1395 \begin{tabular}{l|l|l} 
and Biochemistry & DOI: 10.1159/000485535 & (c) 2017 The Author(s). Published by S. Karger AG, Basel \\
www.karger.com/cpb
\end{tabular} \\ Zhao et al.: Isogambogenic Acid Inhibits Gliom Growth via AMPK-mTOR}

Cell apoptosis detected by flow cytometry

Cells apoptosis was detected by the Annexin V-FITC Apoptosis Detection Kit (BD Bioscience, 556547) according to the manufacturer's protocol. In brief, cells were plated in six-well plates and reached a level of $70-80 \%$ confluence. After treatment, cells were trypsin-released and Annexin-V/PI stained at room temperature for $20 \mathrm{~min}$. Apoptotic cells were measured by Accuri C6 flow cytometer (BD Bioscience) and quantitated.

Transmission electron microscopy detection of the autophagosome

Glioma cells $\left(3 \times 10^{5}\right.$ cells/well) were seeded onto 6-cm dishes for full attachment. After treatment, cells were harvested and fixed using $2.5 \%$ ice-cold glutaraldehyde at $4{ }^{\circ} \mathrm{C}$ overnight. Next, cells were dehydrated with ethanol and acetone. Next, cells were further fixed with $1 \%$ osmium tetroxide for 30 min. Then, cells were embedded in araldite and cut transversely in semithin sections (60 $\mathrm{nm}$ ). The samples were contrasted with lead citrate-uranyl acetate and examined with a transmission electron microscope (Hitachi H-7650, Japan).

\section{Tumour xenograft model}

A total of 21 Female BALB/c nude mice (15-20 g) were purchased from Vital River Laboratory Animal Technology Co. Ltd. (Beijing, China). For tumourigenesis, U87 cells ( 1 x $10^{6}$ cells in $100 \mu$ l of PBS) were inoculated subcutaneously into the right hips of 7- to 8-week-old BALB/c nude mice. Mice were randomly assigned into three groups. When the tumours reached 50 to $70 \mathrm{~mm}^{3}$ in volume (calculated as $\mathrm{V}=\mathrm{L} \times \mathrm{W}^{2} / 2$ ), they were treated with $200 \mu \mathrm{l}$ of isogambogenic acid (1 or $2 \mathrm{mg} / \mathrm{kg}$ in saline) or vehicle (saline) i.p. every 24 hours for 21 days. Tumour size was measured every 3 days for 21 days. After obtaining pictures of mice and tumours, glioma tissues were immediately resected and stored at $-80{ }^{\circ} \mathrm{C}$. All the experimental ethics and animal research were approved by the Animal Care and Ethical Committee of the First Affiliated Hospital of Harbin Medical University.

\section{Immunohistochemistry}

Formalin-fixed, paraffin-embedded samples were sliced into $5 \mu \mathrm{m}$ thick sections. Deparaffinized sections were incubated in $\mathrm{H}_{2} \mathrm{O}_{2}$ for $10 \mathrm{~min}$. In addition, the tumour sections were immunostained for primary antibodies (cleaved caspase-3, 1:200; Ki67, 1:100) at $4{ }^{\circ} \mathrm{C}$ overnight. Secondary antibody (ZSGBBIO, PV6001) was applied for $30 \mathrm{~min}$ at $37^{\circ} \mathrm{C}$. The sections were developed with the Polink-2 plus $®$ Polymer HRP Detection System (ZSGB-BIO, PV-9001) according to the manufacturer's protocol. Next, sections were visualized by using the diaminobenzidine (DAB) substrate kit (ZSGB-BIO, ZLI-9019) for 10 min. After intensive washing, sections were counterstained with haematoxylin, dehydrated and coverslipped. Then, the samples were observed with the FSX100 Bio Imaging Navigator (Olympus, Japan). Data were analysed with Image-Pro Plus 6.0.

\section{Statistical analysis}

Data are presented as the mean \pm SD of three independent experiments. Comparisons between two groups were performed using a two-tailed Student's t-test. A single asterisk indicates statistical significance at $P<0.05$. Double asterisks indicate a strong statistical significance at $P<0.01$. Triple asterisks indicate even stronger statistical significance at $P<0.001$. All statistical analyses were completed using GraphPad Prism 5.0 software.

\section{Results}

\section{Isogambogenic acid inhibits glioma cell growth}

To examine the effect of isogambogenic acid on the viability of the human glioma cell lines U251 and U87, cell viability was determined using the MTT assay. As shown in Fig. $1 \mathrm{~B}$, in both cell lines, cell viability decreased in a dose-dependent manner when treated by isogambogenic acid. The IC50 of isogambogenic acid treatment for $24 \mathrm{~h}$ in glioma cells was 3-4 $\mu \mathrm{M}$. Meanwhile, the immunofluorescent study showed that isogambogenic acid significantly decreased the expression of Ki67 in both cell lines (Fig. 1C). Furthermore, the long-term 


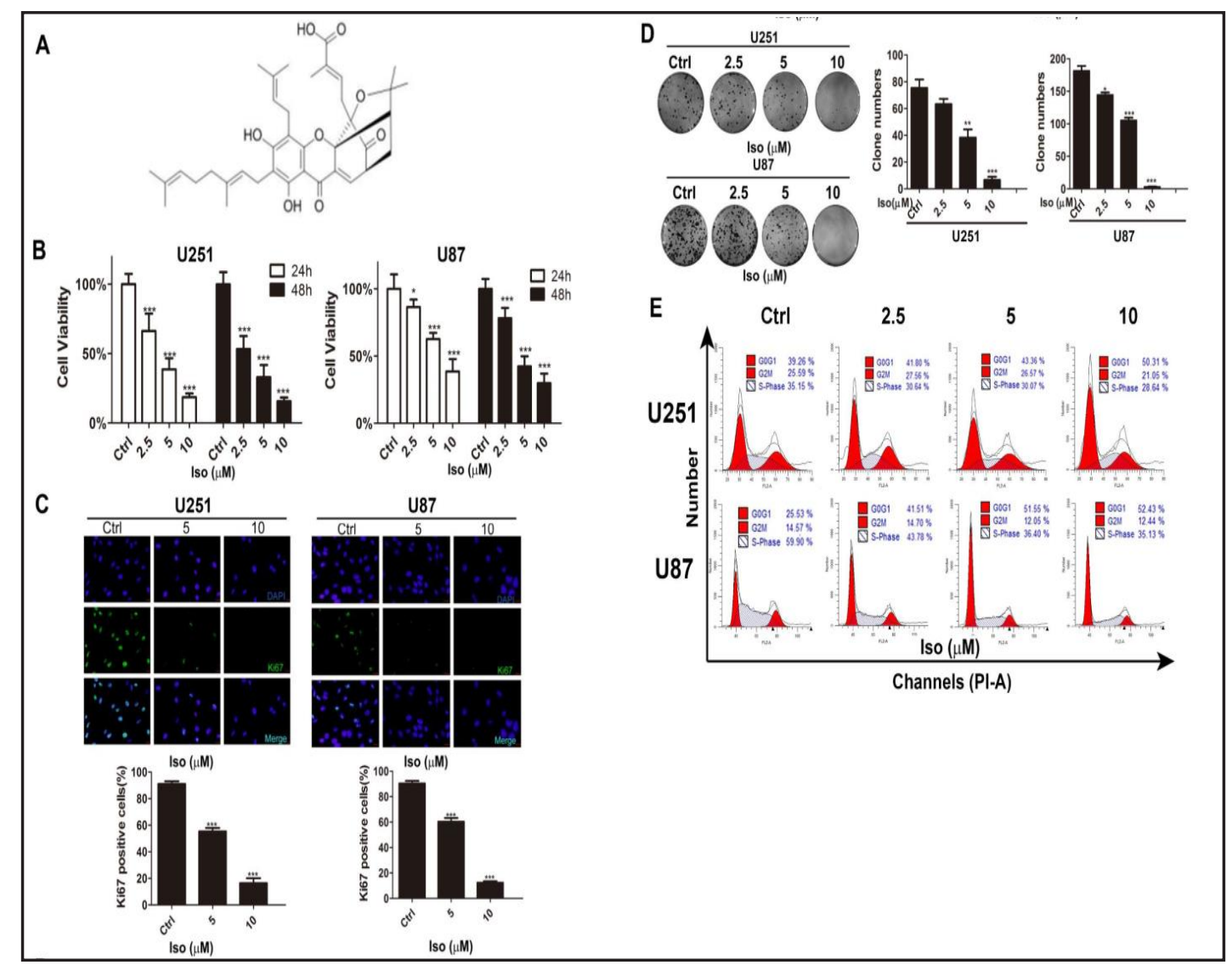

Fig. 1. Isogambogenic acid inhibits glioma cell growth. (A) The chemical structure of isogambogenic acid. (B) U251 or U87 cells were treated with isogambogenic acid for $24 \mathrm{~h}$ or $48 \mathrm{~h}$, and cell viability was measured by the MTT assay. (C) Ki67 expression in tumours from vehicle- or isogambogenic acid-treated U251 or U87 cells was examined by immunofluorescence. The nuclei were stained with DAPI. Red scale bar: $10 \mu \mathrm{m}$. (D) U87 or U251 cell proliferation was examined by the colony formation assay after treatment with isogambogenic acid or vehicle control for 2 weeks. (E) The phase distribution of glioma cells treated with isogambogenic acid for $24 \mathrm{~h}$ was detected by flow cytometry. ${ }^{*} \mathrm{P}<0.05,{ }^{* *} \mathrm{P}<0.01,{ }^{* * *} \mathrm{P}<0.001$ when compared with control. All data are representative of 3 independent experiments.

effects of isogambogenic acid on cell survival were determined by using a colony formation assay. The results showed that isogambogenic acid significantly suppressed the growth of glioma cells, as indicated by the decreased number of cell colonies in the isogambogenic acidtreated group (Fig. 1D). In addition, the results showed that cells in G0/G1 phase increased and cells in the $S$ phase decreased in a relatively dose-dependent manner (Fig. 1E).

\section{Isogambogenic acid induces autophagy in glioma cells}

Increasing evidence has shown that autophagy plays an important role in anticancer therapies; therefore, we next investigated whether isogambogenic acid induces autophagy by examining autophagic vacuoles. With the transfection of Ad-GFP-LC3B, we first detected LC3B puncta formation. As shown, GFP-LC3B fluorescent puncta were increased in the U87 cells in a dose-dependent manner after cells were incubated with isogambogenic acid for $24 \mathrm{~h}$ (Fig. 2A). Furthermore, the conversion of LC3B-I to LC3B-II was also detected in a dose-dependent manner, suggesting that isogambogenic acid induced autophagic flux (Fig. 2B). Moreover, transmission electron microscopy (TEM) analysis showed that autophagic vacuoles containing cellular material or membranous structures were increased in glioma 


\section{Cellular Physiology Cell Physiol Biochem 2017;44:1381-1395 \begin{tabular}{ll|l} 
DOI: 10.1159/000485535 & $\begin{array}{l}\text { O 2017 The Author(s). Published by S. Karger AG, Basel } \\
\text { www.karger.com/cpb }\end{array}$ \\
and Biochemistry Published online: November 30, 201 &
\end{tabular}

cells treated with isogambogenic acid in a dose-dependent manner (Fig. 2C). To further investigate whether isogambogenic acid could alter autophagic degradation, we monitored the levels of SQSTM1, which is associated with LC3 turnover and is lost during autolysosome degradation in a dose-dependent manner following isogambogenic acid incubation (Fig. 2D). Together, these results demonstrated that isogambogenic acid induced autophagosome accumulation and promoted autophagic flux, indicating that isogambogenic acid was a potent autophagic flux inducer.

Inhibition of autophagy in the early or late stage has different effects on isogambogenic acid-induced autophagy

Next, the autophagy inhibitors 3-MA and CQ were used to investigate the role of isogambogenic acid in glioma cells. 3-MA and CQ block the upstream and downstream steps of autophagy [8]. The results indicated that 3-MA $(1 \mathrm{mM})$ attenuated isogambogenic acidinduced cell death, while CQ $(5 \mu \mathrm{M})$ significantly enhanced the isogambogenic acid-induced cytotoxicity (Fig. 3A, B). Then, we detected the autophagy level using TEM and western blot. The data indicated that 3-MA blocked isogambogenic acid-induced autophagy, which was shown by a reduced level of LC3-II and reduced number of autophagic vacuoles (Fig. 3C, D). Unlike 3-MA, CQ treatment led to an isogambogenic acid-induced increase in the

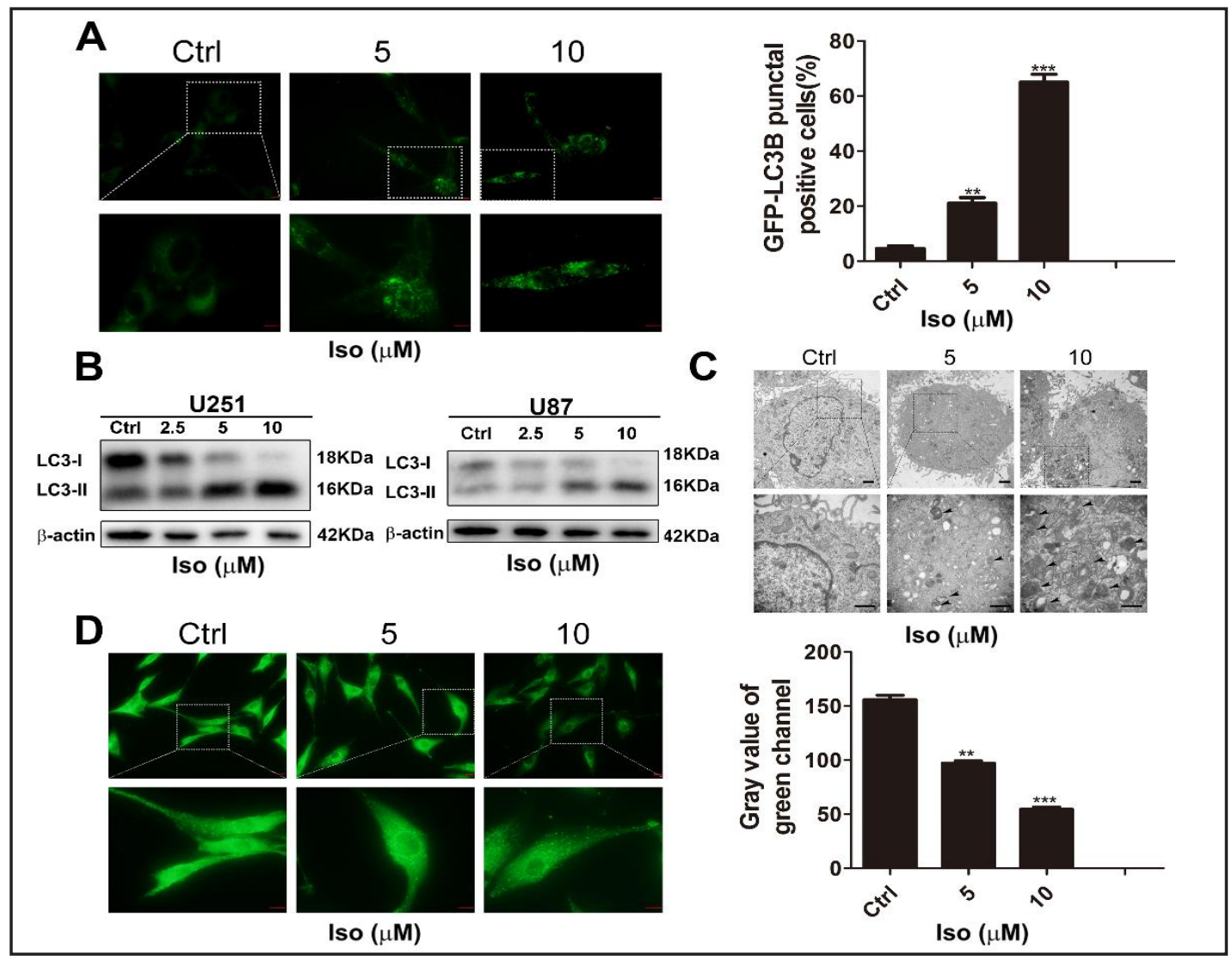

Fig. 2. Isogambogenic acid induces autophagy in glioma cells. (A) GFP-LC3B-expressing U87 cells were treated with isogambogenic acid for $24 \mathrm{~h}$. Formation of GFP-LC3 puncta was demonstrated by fluorescence microscopy. Red scale bar: $5 \mu \mathrm{m}$. (C) Representative electron micrographs of U87 cells treated with isogambogenic acid for $24 \mathrm{~h}$. Scale bar: $2 \mu \mathrm{m}$. (C) U87 cells or U251 cells were treated with isogambogenic acid for $24 \mathrm{~h}$, LC3 expression was examined by western blot. (D) U87 cells were treated with isogambogenic acid for $24 \mathrm{~h}$ and the expression of SQSTM1/p62 was determined by fluorescence microscopy. Red scale bar: $5 \mu \mathrm{m} .{ }^{*} \mathrm{P}<0.05,{ }^{* *} \mathrm{P}<0.01,{ }^{* * *} \mathrm{P}<0.001$ when compared with control. All data are representative of 3 independent experiments.

\section{KARGER}


level of LC3-II and accumulation of autophagic vacuoles (Fig. 3E, F). Collectively, these results suggested that 3-MA suppressed the autophagy and cytotoxicity induced by isogambogenic acid, while CQ enhanced the autophagy and cytotoxicity induced by isogambogenic acid via the accumulation of autophagic vacuoles.

The AMPK-mTOR signalling pathway is involved in isogambogenic acid-induced autophagy

Recently, several studies have suggested that the activation of AMPK promotes autophagosome formation in variouscells, including glioma cells $[10,19]$. Additionally, AMPK has been demonstrated as an inhibitor of the activation of mTOR[20]. Data have shown that mTOR plays an important role in the autophagy of glioma cells [12, 21]. We then examined whether isogambogenic acid had an effect on autophagy via the AMPKmTOR pathway. In this study, we observed that isogambogenic acid induced AMPKo phosphorylation at Thr172 and decreased mTOR phosphorylation at Ser-2448 in a dose-dependent manner in U87 cells. It is well known that mTOR regulates autophagy through the activation of 4E-BP1[12]. Our results demonstrated that isogambogenic acid also inhibited 4E-BP1 phosphorylation at Thr43/46 in glioma cells (Fig. 4A). To further investigate the role of isogambogenic acidinduced AMPK activation in mTOR inhibition, the AMPK activator metformin hydrochloride (Met) and the mTOR inhibitor rapamycin were utilized. The results indicated that pretreatment with Met $(2 \mathrm{mM})$ obviously induced AMPK phosphorylation and inhibited mTOR and 4E-BP1 phosphorylation. Additionally,

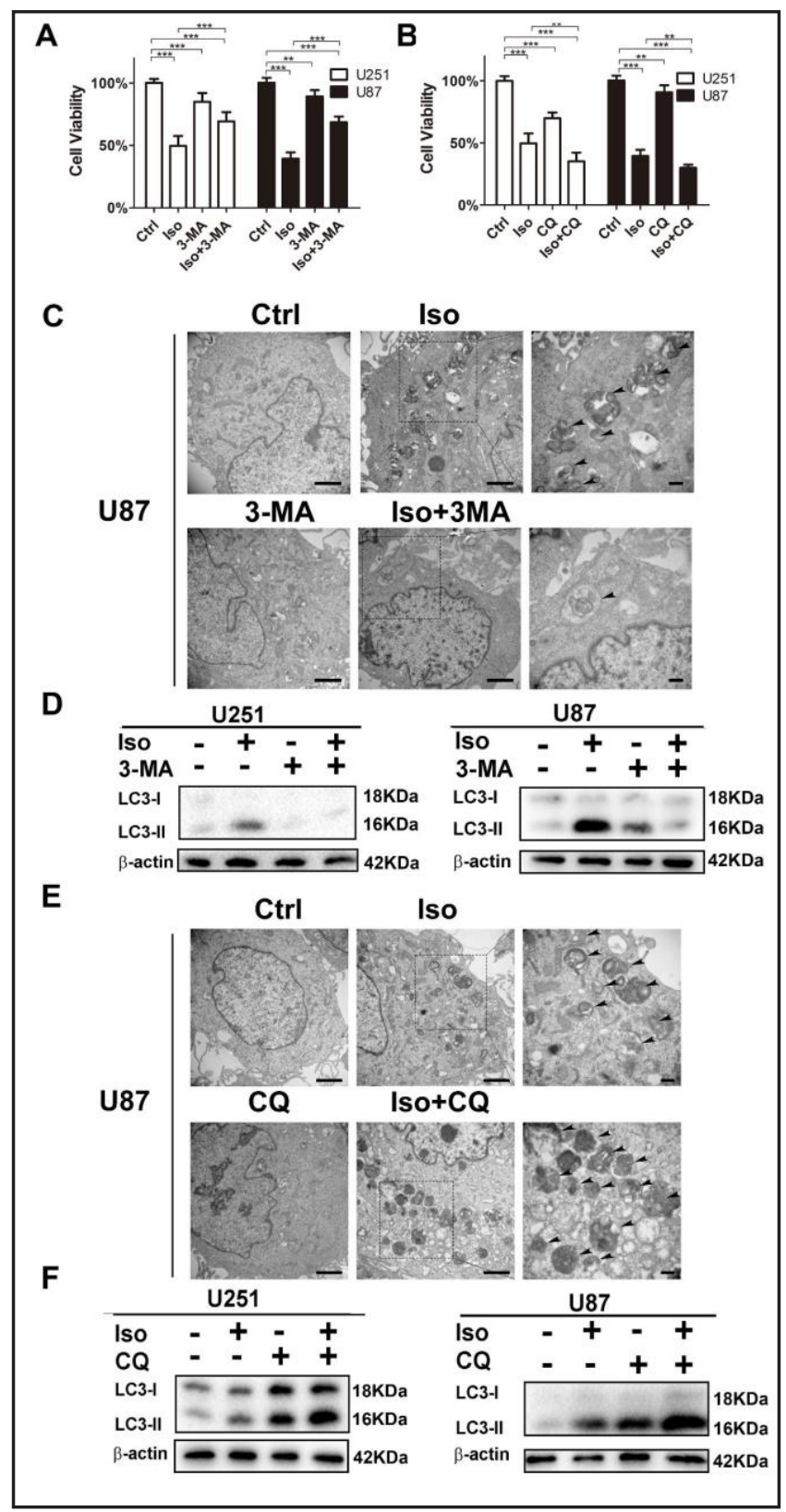

Fig. 3. Inhibition of autophagy in the early or late stage has different effects on isogambogenic acid-induced autophagy. (A, B) U251 and U87 cells were treated with DMSO, 3-MA, or CQ alone or in the presence of isogambogenic acid for $24 \mathrm{~h}$. Cell viability was measured by MTT assay. (C, E) U87 cells were treated with DMSO, 3-MA, or CQ alone or in the presence of isogambogenic acid for $24 \mathrm{~h}$, and the formation of autophagic vacuoles was determined by TEM analysis. Scale bar: $2 \mu \mathrm{m}$. (D, F) U251 and U87 cells were treated with DMSO, 3-MA, or CQ alone or in the presence of isogambogenic acid for $24 \mathrm{~h}$. LC3 expression was examined by western blot. ${ }^{*} \mathrm{P}<0.05$, ${ }^{* *} \mathrm{P}<0.01$, *** $\mathrm{P}<0.001$. All data are representative of 3 independent experiments. 


\section{Cellular Physiology Cell Physiol Biochem 2017;44:1381-1395 \begin{tabular}{ll|l} 
DOI: 10.1159/000485535 & $\begin{array}{l}\text { O } 2017 \text { The Author(s). Published by S. Karger AG, Basel } \\
\text { www.karger.com/cpb }\end{array}$ \\
\hline and Biochemistry Publisned onlne: November 30, 2017
\end{tabular}

our data indicated that co-treatment with Met induced a stronger activation of AMPK and inhibition of mTOR and 4E-BP1 than isogambogenic acid or Met treatment alone in U87 cells (Fig. 4B). Rapamycin (30 nM) obviously inhibited AMPK, mTOR and 4E-BP1 phosphorylation. Our data further indicated that co-treatment with rapamycin induced more AMPK, mTOR and 4E-BP1 inhibition than treatment with isogambogenic acid or rapamycin alone (Fig. 4C). Additionally, our data indicated that co-treatment with isogambogenic acid and Met led to a stronger LC3 conversion and induction of cell death than isogambogenic acid or Met treatment alone (Fig. 5A, B). Furthermore, isogambogenic acid combined with rapamycin induced more LC3 conversion and cytotoxicity than treatment with isogambogenic acid or rapamycin alone (Fig. 5C, D). Therefore, isogambogenic acid appears to be both an AMPK

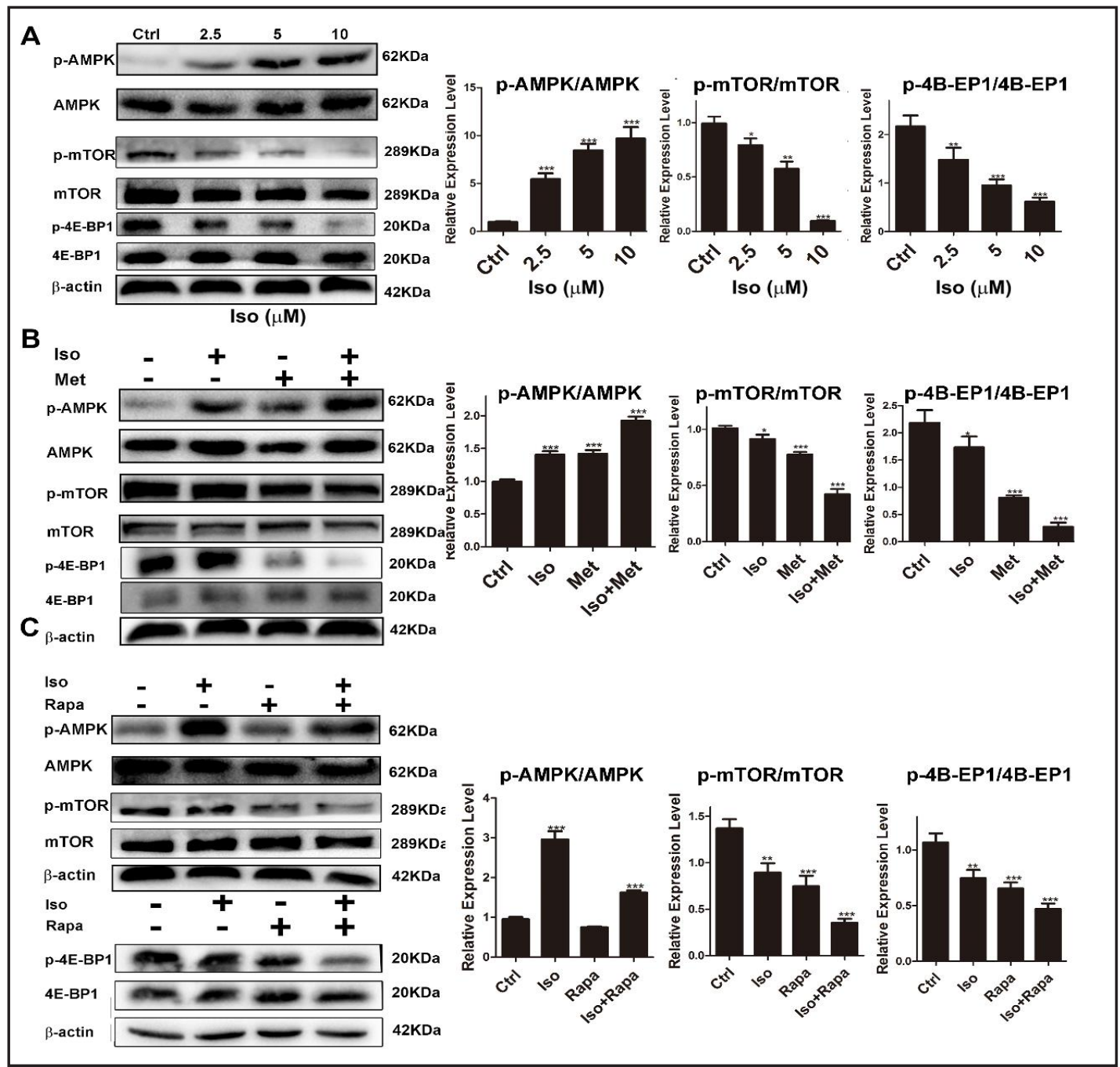

Fig. 4. AMPK-mTOR signalling is involved in isogambogenic acid-induced autophagy. (A) U87 cells were treated with isogambogenic acid for $24 \mathrm{~h}$. Expression levels of the phosphorylation of AMPK, mTOR and 4E-BP1 were assessed by western blotting, and total AMPK, mTOR and 4E-BP1 were used as the internal controls, respectively. (B) U87 cells were treated with Met alone or in the presence of isogambogenic acid for $24 \mathrm{~h}$. The expression levels of phosphorylated AMPK, MTOR and 4E-BP1 were assessed by western blotting, with total AMPK, mTOR and 4E-BP1 used as the internal controls. (C) U87 cells were treated with rapamycin alone or in the presence of isogambogenic acid. Expression levels of phosphorylated AMPK, mTOR and 4EBP1 were assessed by western blotting, with total AMPK, mTOR and 4E-BP1 used as the internal controls. ${ }^{*} \mathrm{P}<0.05,{ }^{* *} \mathrm{P}<0.01,{ }^{* * *} \mathrm{P}<0.001$ when compared with control. All data are representative of 3 independent experiments. 
activator and an mTOR inhibitor. Isogambogenic acid induces autophagy at least partly through the AMPK-mTOR signalling pathway.

\section{Apoptosis occurs in isogambogenic acid-treated glioma cells}

To further evaluate whether isogambogenic acid-induced cell death was associated with apoptosis, the morphological changes of isogambogenic acid-treated glioma cells were examined by Hoechst staining and TEM. Apoptotic cell membrane shrinkage, nuclear membrane shrinkage, chromatin condensation and apoptotic bodies were observed in glioma cells treated with isogambogenic acid for $24 \mathrm{~h}$ (Fig. 6A). Further, we evaluated cleaved caspase-3 protein expression levels and the percentage of apoptotic cells. Isogambogenic acid increased the expression of apoptosis-related cleaved caspase-3 protein and the percentage of Annexin V-positive cells (Fig. 6B). Next, we investigated the relationship between autophagy and apoptosis in isogambogenic acid-treated glioma cells. The results indicated that 3-MA (1 mM) blocked isogambogenic acid-induced $(10 \mu \mathrm{M})$ apoptosis, which was shown by a reduced level of expression of the apoptosis-related cleaved caspase- 3 protein and a lower percentage of Annexin V-positive cells (Fig. 6C). Moreover, we examined whether the AMPK-mTOR pathway had an effect on apoptosis in the isogambogenic acid-treated glioma cells. Our data further indicated that co-treatment with Met $(2 \mathrm{mM})$ induced a higher level of apoptosis than isogambogenic acid $(10 \mu \mathrm{M})$ or Met treatment alone in U87 cells (Fig. 6D). In all, apoptosis occurs in isogambogenic acid-treated glioma cells, and activation of the AMPKmTOR pathway enhanced apoptosis in isogambogenic acid-treated glioma cells.

Isogambogenic acid suppresses glioma growth and induces autophagy in vivo

Next, we investigated the effect of isogambogenic acid on glioma growth in vivo. Data showed that isogambogenic acid reduced the volume and weight of glioma tumours in a

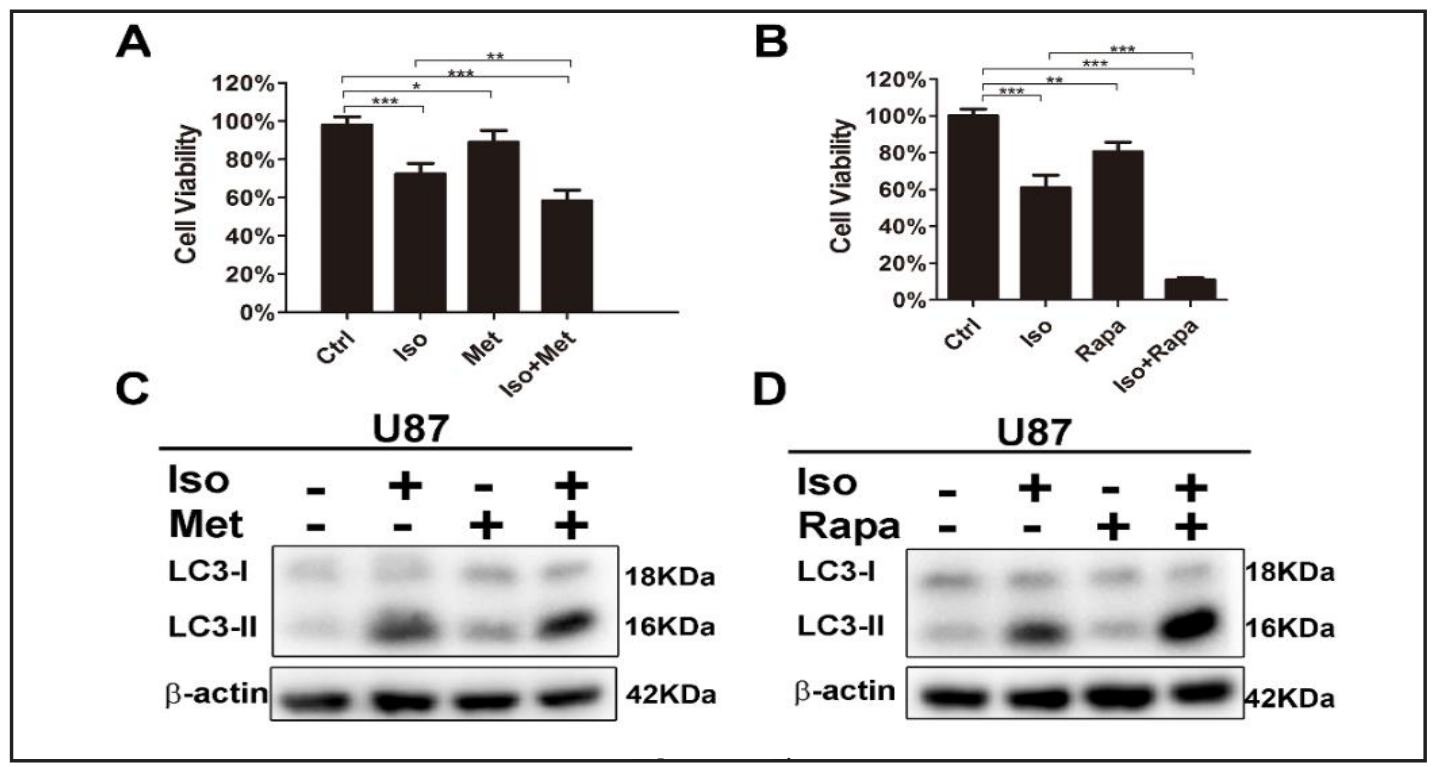

Fig. 5. AMPK-mTOR pathway mediates the induction of autophagy by isogambogenic acid treatment in glioma cells. (A) U87 cells were treated with DMSO or with Met either alone or in the presence of isogambogenic acid for $24 \mathrm{~h}$. Cell viability was measured by MTT assay. (B) U87 cells were treated with DMSO or with rapamycin either alone or in the presence of isogambogenic acid for $24 \mathrm{~h}$. Cell viability was measured by MTT assay. (C) U87 cells were treated with DMSO or with Met either alone or in the presence of isogambogenic acid. LC3 expression was examined by western blot. (D) U87 cells were treated with DMSO or with rapamycin either alone or in the presence of isogambogenic acid for $24 \mathrm{~h}$. LC3 expression was examined by western blot. ${ }^{*} \mathrm{P}<0.05,{ }^{* *} \mathrm{P}<0.01,{ }^{* * *} \mathrm{P}<0.001$. All data are representative of 3 independent experiments. 
concentration-dependent manner (Fig. 7A, B). Next, we examined the relationship between isogambogenic acid and autophagy in glioma. As shown in Fig. 7C, the protein expressions of LC3II/LC3-I in the tumours of the isogambogenic acid group were higher than in the salinetreated group. In addition, elevated phosphorylation levels of AMPK and cleavedcaspase- 3 and a decreased expression of Ki67 were observed in the isogambogenic acid-treated group compared with the controls in vivo (Fig. 7D, E). All together, these data supported isogambogenic acidmediated growth suppression of glioma related to the AMPKmTOR pathway and autophagic and apoptotic cell death in vivo.

\section{Discussion}

In recent years, many studies have focused on identifying anti-glioma agents that can suppress tumour growth with fewer side effects [22-24]. It has been well established that autophagy is closely implicated in the occurrence and development of glioma [10, 25]. Intervening in autophagy has been accepted as one of the effective measures for glioma treatment $[26,27]$. Our results, as shown in Fig. 8, suggested for the first time that isogambogenic acid induced autophagy and apoptosis and decreased the expression of Ki67 and colony formation in vitro and in vivo. Isogambogenic acid will be a potent anti-glioma agent after further research.

In this study, we investigated that isogambogenic acid suppressed cell growth and the expression level of Ki67, an important proliferative marker. According to relevant research

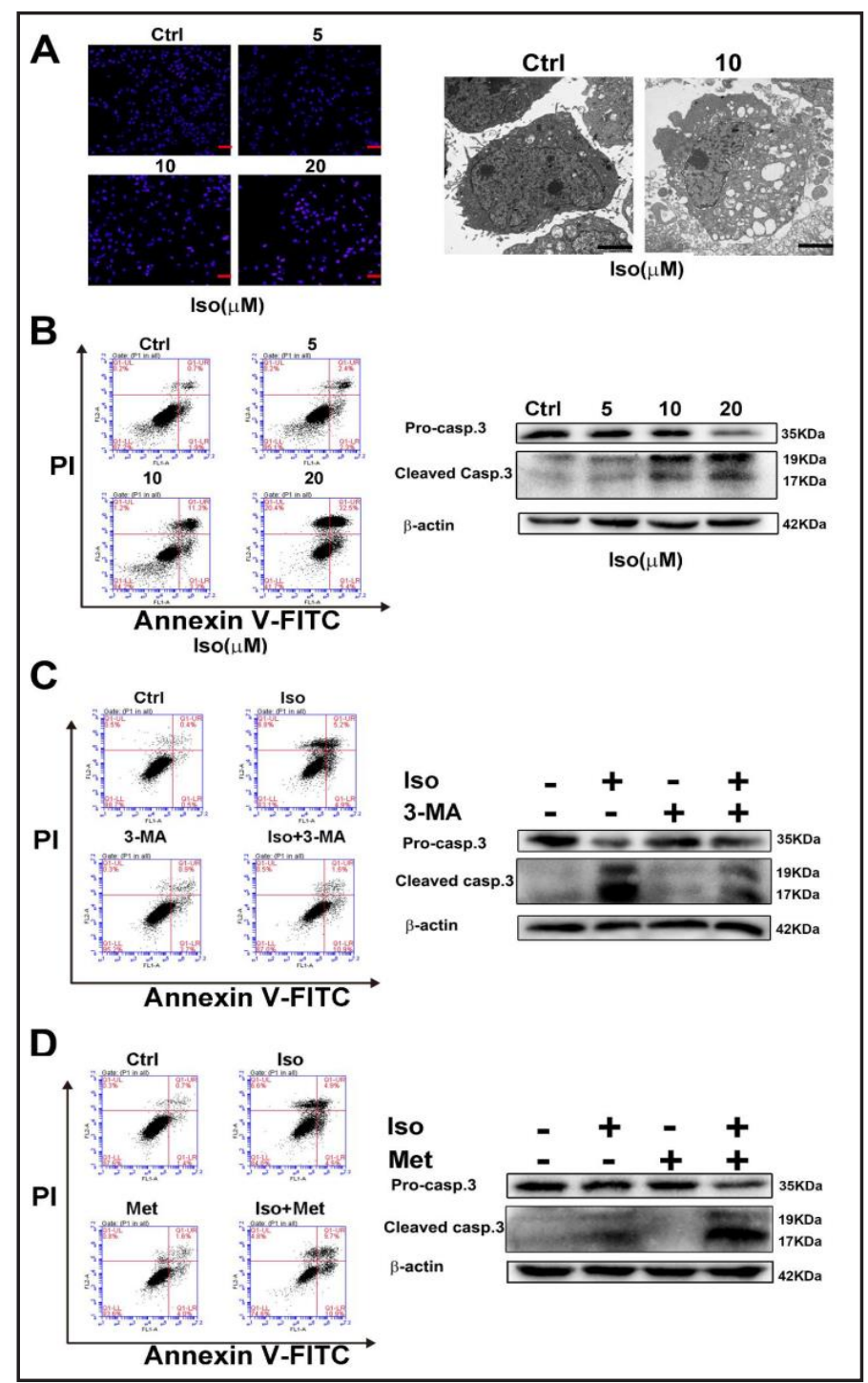

Fig. 6. Apoptosis occurs in isogambogenic acid-treated glioma cells. (A) Hoechst staining and TEM results showed the morphological changes of U87 cells treated with isogambogenic acid for $24 \mathrm{~h}$. Red scale bar: $200 \mu \mathrm{m}$. Black scale bar: $2 \mu \mathrm{m}$. (B) After isogambogenic acid treatment for $24 \mathrm{~h}$, the U87 cells were analysed by flow cytometry and examined by western blot for the apoptosis-related protein caspase-3. (C) After treatment with DMSO or with 3-MA either alone or in the presence of isogambogenic acid for $24 \mathrm{~h}$, the U87 cells were analysed by flow cytometry and examined by western blot for the apoptosis-related protein caspase-3. (D) After treatment with DMSO or with Met either alone or in the presence of isogambogenic acid for $24 \mathrm{~h}$, the U87 cells were analysed by flow cytometry and examined by western blot for apoptosis related proteins caspase- 3 . * $\mathrm{P}<0.05$, ** $\mathrm{P}<0.01$, *** $\mathrm{P}<0.001$ when compared with the control. All data are representative of 3 independent experiments. 


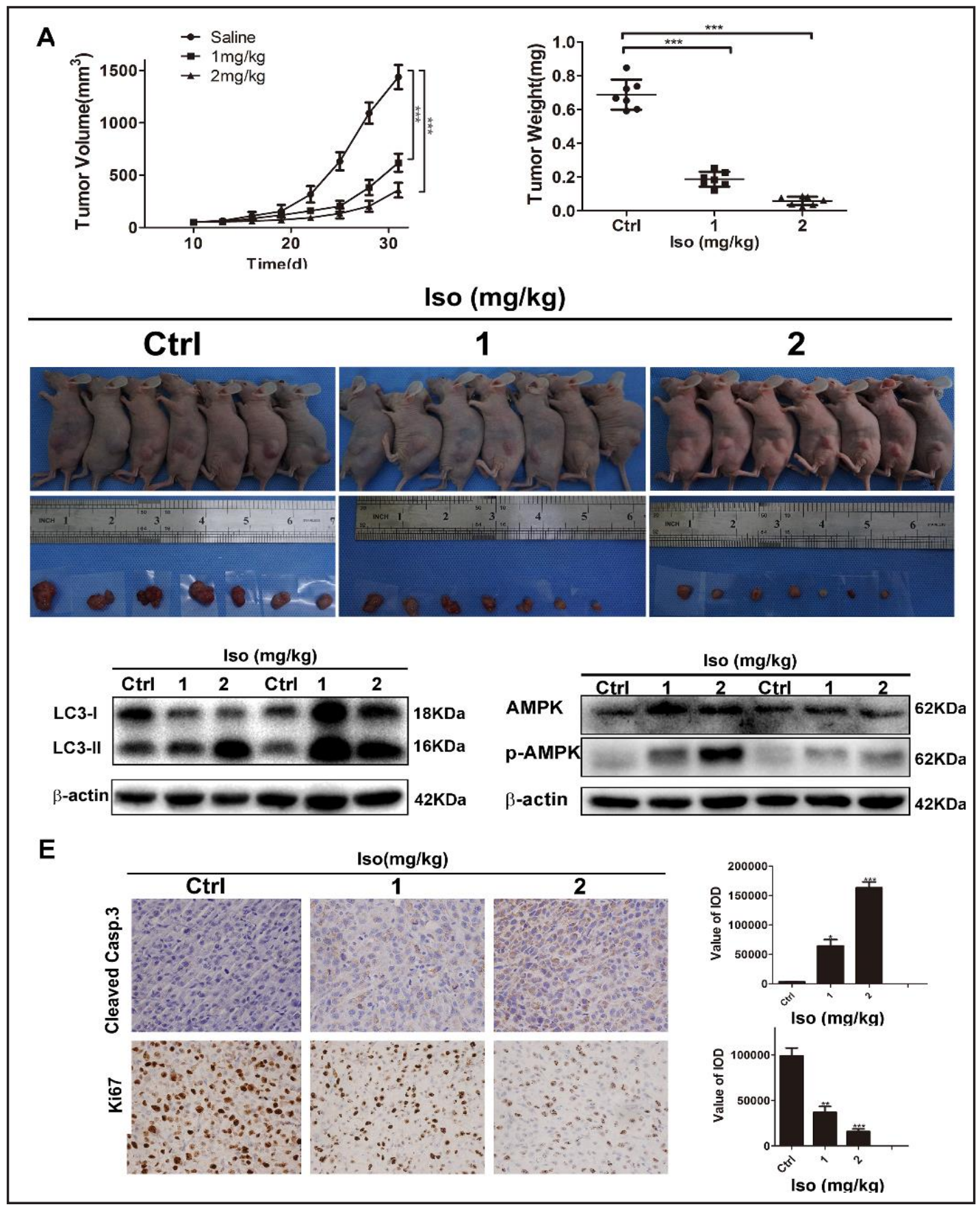

Fig. 7. Isogambogenic acid suppresses tumour growth and induces autophagy in vivo. (A) Tumour volume and tumour weights were measured for $21 \mathrm{~d}$. (B) Representative images of mice with xenograft U87 tumours were photographed after treatment with either isogambogenic acid or saline. (C) LC3 expression was examined by western blot (two samples in each group were shown) after isogambogenic acid treatment in vivo. (D) Western blotting of the change in AMPK and p-AMPK expression (two samples in each group were shown) levels in vivo. (G) Immunohistochemistry of Ki67 and cleaved caspase-3 in vivo (magnification, $\mathrm{x} 400){ }^{*} \mathrm{P}<0.05$, ${ }^{* *} \mathrm{P}<0.01$, ${ }^{* * *} \mathrm{P}<0.001$ when compared with the control. All data are representative of 3 independent experiments.

reports, isogambogenic acid has low toxicity to zebrafish embryos [28]. In addition, recent studies show that cell cycle regulation is an attractive target in cancer therapy, especially in

\section{KARGER}


Fig. 8. Schematic diagram that illustrates a hypothetical mechanism of signalling of isogambogenic acidtreated glioma.

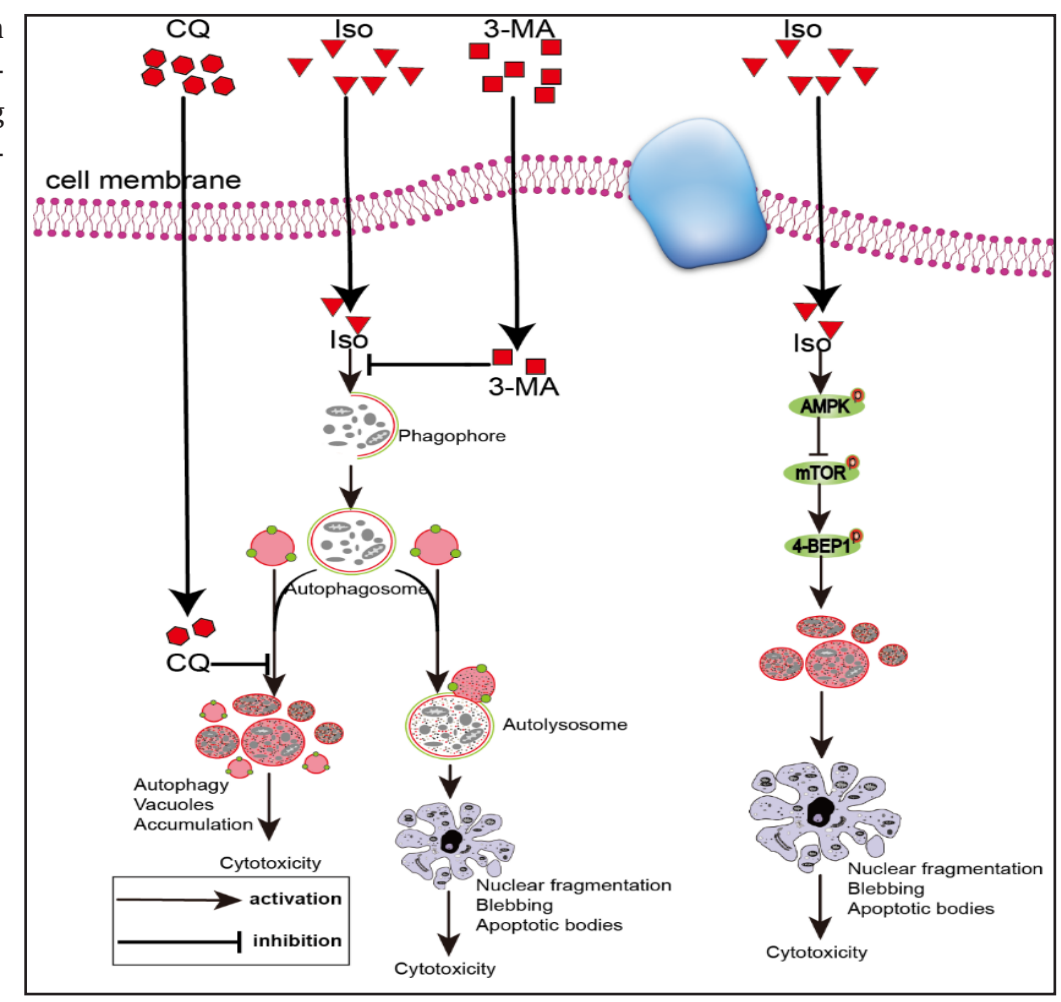

gliomas $[29,30]$. Cell cycle arrest triggers tumour senescence and prevents tumour progression and have not any obvious effects on normal tissues, which may be related to the inhibition of regulators such as CDK1, D-type cyclins, CDK4 and CDK6[31, 32]. Our data showed that isogambogenic acid led to cell cycle arrest in human glioma U87 and U251 cells, so this drug has a good toxicity against gliomas and may have a low toxicity in normal tissues. In addition, isogambogenic acid can disrupt autophagy and stimulate apoptosis and the mechanisms of drug action is associated with AMPK and mTOR related pathways. The activation of these pathways in normal cells is markedly different from that of tumours, so it can be inferred that isogambogenic acid may have little effect on normal cells [13, 33].

Further experiments on the increased conversion of LC3-I to LC3-II, SQSTM1 clearance and massive autophagic vacuoles in isogambogenic acid-treated glioma cells suggested that autophagy was activated by isogambogenic acid. In addition, another finding indicated that isogambogenic acid-related autophagy can be strengthened by inhibiting the late stage of autophagy. Increased conversion of LC3-I to LC3-II and massive autophagic vacuoles induced by isogambogenic acid can be attenuated by 3-MA but strengthened by CQ. This suggested that 3-MA inhibited autophagy flux initiation and attenuated isogambogenic acid-related autophagy. CQ inhibited autophagosome-lysosome fusion and the degradation steps induced by isogambogenic acid, enhancing autophagic vacuole accumulation and the cytotoxic effects of isogambogenic acid on glioma cells.

Furthermore, our data indicated that the effects of isogambogenic acid on glioma cells are associated with the AMPK-mTOR signalling pathway. As is well recognized, the key role of mTOR is as a repressor of autophagy; the decrease in mTOR activity can effectively initiate the autophagic response in glioma cells [34-36]. Activation of AMPK leads to the inhibition of mTOR, which also propels autophagy [33]. In line with our study, previous evidence has shown that activation of the AMPK-mTOR pathway induces autophagy in glioma cells [37]. In this report, we found that isogambogenic acid-induced autophagy was associated with the AMPK-mTOR pathway and that isogambogenic acid attenuated mTOR signalling via activation of the AMPK-dependent pathway. Moreover, activation of the AMPK-mTOR pathway enhanced isogambogenic acid-induced autophagy and inhibited the growth of 
glioma cells, which further indicates that isogambogenic acid inhibits induced autophagy and the growth of glioma cells through activation of the AMPK-mTOR pathway.

As we know, programmed cell death can be divided into apoptotic and autophagic cell death. Until now, studies have shown three different effects of autophagy on apoptosis to induce cell death: antagonizing apoptosis, facilitating apoptosis or cooperating with apoptosis [38]. In normal cells, the onset of moderate autophagy usually inhibits the occurrence of apoptosis [39]. However, excessive autophagy in cells stimulated by drugs and other factors may play an important role in apoptosis [40, 41]. In the present study, we found that both apoptosis and autophagy were induced after isogambogenic acid treatment. Fig. 8 depicts the hypothesized mechanism of isogambogenic acid-induced autophagy and apoptosis in gliomas. Inhibition of autophagy by 3-MA led to a decreased apoptosis level, indicating that autophagy may act as an apoptosis promoter to induce glioma cell death after isogambogenic acid treatment and that inhibition of the early steps of autophagy reduced caspase-dependent cell death [42]. Autophagy contributes to apoptosis by several different means, such as enabling membrane blebbing and phosphatidylserine exposure by maintaining ATP levels [43]. Similar to our results, studies by Young et al. found that autophagosome formation has been implicated in the process of apoptosis. Moreover, they found that inhibition of the early stage of autophagy reduced the activation of caspase- 8 and caspase-3, while the effect of late autophagy inhibition was the opposite [42]. In addition to autophagy, several studies have shown that the activation of AMPK and inhibition of MTOR is closely related to apoptosis [44-47]. In our study, activation of the AMPK-mTOR pathway led to a higher amount of apoptosis, which suggests that the AMPK-mTOR pathway may also contribute to isogambogenic acid-induced apoptosis in glioma cells. Nevertheless, the antineoplastic mechanisms of isogambogenic acid are complex. The relationship between the autophagy and apoptosis induced by isogambogenic acid and the underlying mechanisms are worthy of further exploration.

\section{Conclusion}

Our work shows that isogambogenic acid, a natural autophagic inducer, induces autophagy and apoptosis by regulating the AMPK-mTOR pathway in glioma cells. In addition, targeting autophagy, apoptosis and related signalling pathways may provide new strategies for glioma treatment.

\section{Acknowledgements}

This study was financially supported by grants from the National Natural Science Foundation of China (grant nos. 81272788, 81472368, 81372701).

\section{Disclosure Statement}

The authors have no conflicts of interest to declare.

\section{References}

1 Omuro A, DeAngelis LM: Glioblastoma and other malignant gliomas: a clinical review. Jama 2013;310:18421850.

-2 Wang L, Wei Q Wang LE, Aldape KD, Cao Y, Okcu MF, Hess KR, El-Zein R, Gilbert MR, Woo SY, Prabhu SS, Fuller GN, Bondy ML: Survival prediction in patients with glioblastoma multiforme by human telomerase genetic variation. J Clin Oncol 2006;24:1627-1632. 


\section{Cellular Physiology Cell Physiol Biochem 2017;44:1381-1395 \begin{tabular}{ll|l} 
DOI: 10.1159/000485535 & $\begin{array}{l}\text { O 2017 The Author(s). Published by S. Karger AG, Basel } \\
\text { www.karger.com/cpb }\end{array}$
\end{tabular}}

-3 Stupp R, Mason WP, van den Bent MJ, Weller M, Fisher B, Taphoorn MJ, Belanger K, Brandes AA, Marosi C, Bogdahn U, Curschmann J, Janzer RC, Ludwin SK, Gorlia T, Allgeier A, Lacombe D, Cairncross JG, Eisenhauer E, Mirimanoff RO: Radiotherapy plus concomitant and adjuvant temozolomide for glioblastoma. N Engl J Med 2005;352:987-996.

4 Mathew R, Karantza-Wadsworth V, White E: Role of autophagy in cancer. Nat Rev Cancer 2007;7:961-967.

5 Amaravadi RK, Lippincott-Schwartz J, Yin XM, Weiss WA, Takebe N, Timmer W, DiPaola RS, Lotze MT, White E: Principles and current strategies for targeting autophagy for cancer treatment. Clin Cancer Res 2011;17:654-666.

6 Shchors K, Massaras A, Hanahan D: Dual Targeting of the Autophagic Regulatory Circuitry in Gliomas with Repurposed Drugs Elicits Cell-Lethal Autophagy and Therapeutic Benefit. Cancer Cell 2015;28:456-471.

7 Kondo Y, Kondo S: Autophagy and cancer therapy. Autophagy 2006;2:85-90.

$>8$ Li C, Liu Y, Liu H, Zhang W, Shen C, Cho K, Chen X, Peng F, Bi Y, Hou X, Yang Z, Zheng Z, Wang K, Wang X, Zhang J, Zhong C, Zou H, Zhang X, Zhao S: Impact of autophagy inhibition at different stages on cytotoxic effect of autophagy inducer in glioblastoma cells. Cell Physiol Biochem 2015;35:1303-1316.

-9 Rikiishi H: Novel Insights into the Interplay between Apoptosis and Autophagy. Int J Cell Biol 2012;2012:317645.

10 Li W, Saud SM, Young MR, Chen G, Hua B: Targeting AMPK for cancer prevention and treatment. Oncotarget 2015;6:7365-7378.

11 Dasgupta B, Chhipa RR: Evolving Lessons on the Complex Role of AMPK in Normal Physiology and Cancer. Trends Pharmacol Sci 2016;37:192-206.

12 Chiarini F, Evangelisti C, McCubrey JA, Martelli AM: Current treatment strategies for inhibiting mTOR in cancer. Trends Pharmacol Sci 2015;36:124-135.

13 Laplante M, Sabatini DM: mTOR signaling in growth control and disease. Cell 2012;149:274-293.

14 Liu R, Li J, Zhang T, Zou L, Chen Y, Wang K, Lei Y, Yuan K, Li Y, Lan J, Cheng L, Xie N, Xiang R, Nice EC, Huang C, Wei Y: Itraconazole suppresses the growth of glioblastoma through induction of autophagy: involvement of abnormal cholesterol trafficking. Autophagy 2014;10:1241-1255.

-15 Inoki K, Zhu T, Guan KL: TSC2 mediates cellular energy response to control cell growth and survival. Cell 2003;115:577-590.

16 Wu WD, Hu ZM, Shang MJ, Zhao DJ, Zhang CW, Hong DF, Huang DS: Cordycepin down-regulates multiple drug resistant (MDR)/HIF-1alpha through regulating AMPK/mTORC1 signaling in GBC-SD gallbladder cancer cells. Int J Mol Sci 2014;15:12778-12790.

17 Tripathi DN, Chowdhury R, Trudel LJ, Tee AR, Slack RS, Walker CL, Wogan GN: Reactive nitrogen species regulate autophagy through ATM-AMPK-TSC2-mediated suppression of mTORC1. Proc Natl Acad Sci U S A 2013;110:E2950-2957.

18 Yang J, Zhou Y, Cheng X, Fan Y, He S, Li S, Ye H, Xie C, Wu W, Li C, Pei H, Li L, Wei Z, Peng A, Wei Y, Li W, Chen L: Isogambogenic acid induces apoptosis-independent autophagic cell death in human non-small-cell lung carcinoma cells. Sci Rep 2015;5:7697.

19 Zhang CS, Lin SC: AMPK Promotes Autophagy by Facilitating Mitochondrial Fission. Cell Metab 2016;23:399401.

-20 Liu X, Xiao ZD, Han L, Zhang J, Lee SW, Wang W, Lee H, Zhuang L, Chen J, Lin HK, Wang J, Liang H, Gan B: LncRNA NBR2 engages a metabolic checkpoint by regulating AMPK under energy stress. Nat Cell Biol 2016;18:431-442.

21 Tanaka K, Sasayama T, Irino Y, Takata K, Nagashima H, Satoh N, Kyotani K, Mizowaki T, Imahori T, Ejima Y, Masui K, Gini B, Yang H, Hosoda K, Sasaki R, Mischel PS, Kohmura E: Compensatory glutamine metabolism promotes glioblastoma resistance to mTOR inhibitor treatment. J Clin Invest 2015;125:1591-1602.

22 Oberoi RK, Parrish KE, Sio TT, Mittapalli RK, Elmquist WF, Sarkaria JN: Strategies to improve delivery of anticancer drugs across the blood-brain barrier to treat glioblastoma. Neuro Oncol 2016;18:27-36.

23 Parrish KE, Sarkaria JN, Elmquist WF: Improving drug delivery to primary and metastatic brain tumors: strategies to overcome the blood-brain barrier. Clin Pharmacol Ther 2015;97:336-346.

24 Prados MD, Byron SA, Tran NL, Phillips JJ, Molinaro AM, Ligon KL, Wen PY, Kuhn JG, Mellinghoff IK, de Groot JF, Colman H, Cloughesy TF, Chang SM, Ryken TC, Tembe WD, Kiefer JA, Berens ME, Craig DW, Carpten JD, Trent JM: Toward precision medicine in glioblastoma: the promise and the challenges. Neuro Oncol 2015;17:10511063.

25 Shipman L: Glioma: Repurposed drugs combined to amplify autophagy. Nat Rev Cancer 2015;15:636. 


\section{Cellular Physiology Cell Physiol Biochem 2017;44:1381-1395 \begin{tabular}{ll|l} 
DOI: 10.1159/000485535 & $\begin{array}{l}\text { O 2017 The Author(s). Published by S. Karger AG, Basel } \\
\text { www.karger.com/cpb }\end{array}$ \\
\hline
\end{tabular}}

Zhao et al.: Isogambogenic Acid Inhibits Gliom Growth via AMPK-mTOR

-26 Liu WT, Lin CH, Hsiao M, Gean PW: Minocycline inhibits the growth of glioma by inducing autophagy. Autophagy 2011;7:166-175.

-27 Vucicevic L, Misirkic M, Janjetovic K, Vilimanovich U, Sudar E, Isenovic E, Prica M, Harhaji-Trajkovic L, KravicStevovic T, Bumbasirevic V, Trajkovic V: Compound C induces protective autophagy in cancer cells through AMPK inhibition-independent blockade of Akt/mTOR pathway. Autophagy 2011;7:40-50.

-28 Fan Y, Peng A, He S, Shao X, Nie C, Chen L: Isogambogenic acid inhibits tumour angiogenesis by suppressing Rho GTPases and vascular endothelial growth factor receptor 2 signalling pathway. J Chemother 2013;25:298308.

-29 Otto T, Sicinski P: Cell cycle proteins as promising targets in cancer therapy. Nat Rev Cancer 2017;17:93-115.

-30 Thomas AA, Brennan CW, DeAngelis LM, Omuro AM: Emerging therapies for glioblastoma. JAMA neurology 2014;71:1437-1444.

-31 Horiuchi D, Kusdra L, Huskey NE, Chandriani S, Lenburg ME, Gonzalez-Angulo AM, Creasman KJ, Bazarov AV, Smyth JW, Davis SE, Yaswen P, Mills GB, Esserman LJ, Goga A: MYC pathway activation in triple-negative breast cancer is synthetic lethal with CDK inhibition. J Exp Med 2012;209:679-696.

-32 Choi YJ, Li X, Hydbring P, Sanda T, Stefano J, Christie AL, Signoretti S, Look AT, Kung AL, von Boehmer H, Sicinski P: The requirement for cyclin D function in tumor maintenance. Cancer Cell 2012;22:438-451.

-33 Inoki K, Kim J, Guan KL: AMPK and mTOR in cellular energy homeostasis and drug targets. Annu Rev Pharmacol Toxicol 2012;52:381-400.

-34 Lin F, de Gooijer MC, Hanekamp D, Chandrasekaran G, Buil LC, Thota N, Sparidans RW, Beijnen JH, Wurdinger T, van Tellingen O: PI3K-mTOR Pathway Inhibition Exhibits Efficacy Against High-grade Glioma in Clinically Relevant Mouse Models. Clin Cancer Res 2017;23:1286-1298.

-35 Becker CM, Oberoi RK, McFarren SJ, Muldoon DM, Pafundi DH, Pokorny JL, Brinkmann DH, Ohlfest JR, Sarkaria JN, Largaespada DA, Elmquist WF: Decreased affinity for efflux transporters increases brain penetrance and molecular targeting of a PI3K/mTOR inhibitor in a mouse model of glioblastoma. Neuro Oncol 2015;17:1210-1219.

-36 Zhang C, Yuan XR, Li HY, Zhao ZJ, Liao YW, Wang XY, Su J, Sang SS, Liu Q: Anti-cancer effect of metabotropic glutamate receptor 1 inhibition in human glioma U87 cells: involvement of PI3K/Akt/mTOR pathway. Cell Physiol Biochem 2015;35:419-432.

-37 Wang J, Qi Q, Feng Z, Zhang X, Huang B, Chen A, Prestegarden L, Li X, Wang J: Berberine induces autophagy in glioblastoma by targeting the AMPK/mTOR/ULK1-pathway. Oncotarget 2016;7:66944-66958.

-38 Jain MV, Paczulla AM, Klonisch T, Dimgba FN, Rao SB, Roberg K, Schweizer F, Lengerke C, Davoodpour P, Palicharla VR, Maddika S, Los M: Interconnections between apoptotic, autophagic and necrotic pathways: implications for cancer therapy development. J Cell Mol Med 2013;17:12-29.

-39 Fuchs Y, Steller H: Live to die another way: modes of programmed cell death and the signals emanating from dying cells. Nat Rev Mol Cell Biol 2015;16:329-344.

40 Green DR, Llambi F: Cell Death Signaling. Cold Spring Harb Perspect Biol 2015;7.

-41 Lockshin RA: Programmed cell death 50 (and beyond). Cell Death Differ 2016;23:10-17.

42 Young MM, Takahashi Y, Khan O, Park S, Hori T, Yun J, Sharma AK, Amin S, Hu CD, Zhang J, Kester M, Wang HG: Autophagosomal membrane serves as platform for intracellular death-inducing signaling complex (iDISC)mediated caspase-8 activation and apoptosis. J Biol Chem 2012;287:12455-12468.

-43 Bovellan M, Fritzsche M, Stevens C, Charras G: Death-associated protein kinase (DAPK) and signal transduction: blebbing in programmed cell death. Febs j 2010;277:58-65.

44 Jang JE, Eom JI, Jeung HK, Cheong JW, Lee JY, Kim JS, Min YH: AMPK-ULK1-Mediated Autophagy Confers Resistance to BET Inhibitor JQ1 in Acute Myeloid Leukemia Stem Cells. Clin Cancer Res 2017;23:2781-2794.

45 Liu X, Hu X, Kuang Y, Yan P, Li L, Li C, Tao Q Cai X: BCLB, methylated in hepatocellular carcinoma, is a starvation stress sensor that induces apoptosis and autophagy through the AMPK-mTOR signaling cascade. Cancer Lett 2017;395:63-71.

46 Perumal D, Kuo PY, Leshchenko VV, Jiang Z, Divakar SK, Cho HJ, Chari A, Brody J, Reddy MV, Zhang W, Reddy EP, Jagannath S, Parekh S: Dual Targeting of CDK4 and ARK5 Using a Novel Kinase Inhibitor ON123300 Exerts Potent Anticancer Activity against Multiple Myeloma. Cancer Res 2016;76:1225-1236.

- 47 Song X, Kim SY, Zhang L, Tang D, Bartlett DL, Kwon YT, Lee YJ: Role of AMP-activated protein kinase in crosstalk between apoptosis and autophagy in human colon cancer. Cell Death Dis 2014;5:e1504. 